\title{
STILL DYING FOR A LIVING: CORPORATE CRIMINAL LIABILITY AFTER THE Westray Mine Disaster, Steven Bittle (VAncouver: UBC Press, 2012)
}

You used to say it yourself — we keep the lowlifes around so we can have a dartboard we can hit. ${ }^{1}$

The kind of cases the police deal with every day — the robberies, the rapes, the assaults, the murders everyone knows they're crimes. Many of them are done by bad people; many, too, by those just trying to survive. For those crimes, people get punished. But there are some crimes that society isn't equipped to punish; instead the perpetrators of those crimes are rewarded. ${ }^{2}$

Early in the morning of 9 May 1992, an explosion occurred in the Westray coal mine in Plymouth, Nova Scotia. Methane gas ignited, leading to coal-dust detonations. Twenty-six miners were killed. ${ }^{3}$ On 15 May 1992, Justice K. Peter Richard was appointed to inquire into and report on the disaster. ${ }^{4}$ In his 1997 report, Justice Richard stated that

\begin{abstract}
The evidence before this Inquiry compels but one conclusion - the Westray operation defied the fundamental rules and principles of safe mining practice. Regardless of the theories, philosophies, and procedures that management espoused on paper, most notably in its employee handbook, it clearly rejected industry standards, provincial regulations, codes of safe practice, and common sense in the operation of the Westray mine. Management failed to adopt and effectively promote a safety ethic underground. Instead, management, through its actions and attitudes, sent a different message - Westray was to produce coal at the expense of worker safety.
\end{abstract}

Westray management, from the chief executive officer, Clifford Frame, and the mine manager, Gerald Phillips, down to the line supervisor, had a fundamental duty to instil in the underground worker a respect for safety beyond other considerations. Management could do this through training, by example, and with continued monitoring at all levels. In trivializing and ignoring safety concerns, Westray management was significantly derelict in its duty to the workforce and seemed actively to promote a disdainful and reckless attitude towards safe mining practices. ${ }^{5}$

Corporate officials and Curragh Inc. (Curragh), ${ }^{6}$ the corporate mine operator, were charged with 52 offences under Nova Scotia occupational health and safety legislation. Some 34 of these charges were judicially stayed because of the criminal investigation into the

James Lee Burke, Black Cherry Blues (New York: HarperCollins, 1989) at 105.

Daniel Blake, City of the Dead (New York: Pocket Books, 2011) at 486.

See Justice K Peter Richard, The Westray Story: A Predictable Path to Disaster (Report of the Westray Public Inquiry, 1997), online: Province of Nova Scotia <http://novascotia.ca/lae/pubs/westray/exec summ.asp> [Westray Report]; Westray Report, ibid, “Chapter 6: The Explosion,” online: Province of Nova Scotia <http://novascotia.ca/lae/pubs/westray/findings.asp>.

4 Justice Richard was appointed by Order in Council 92-504 under the Public Inquiries Act, RSNS 1989, c 372 and the Coal Mines Regulation Act, RSNS 1989, c 73; Government of Nova Scotia, Order in Council Details, online: Province of Nova Scotia <http://www.gov.ns.ca/exec_council/oic/view. asp?oicID $=1448>$.

5 Westray Report, supra note 3, “Chapter 5: Working Underground at Westray,” online: Province of Nova Scotia <http://novascotia.ca/lae/ pubs/westray/findings.asp>.

$6 \quad$ Previously named Curragh Resources Inc. Its name was changed two days before the explosion: See Yukon Legislative Assembly, Hansard 27th Leg 3rd Sess (7 May 1992), online: Yukon Legislative Assembly <http://www.hansard.gov.yk.ca/27-legislature/session3/011_May_7_1992.html>; Ivan Smith, "Westray Coal Mine Disaster" (9 May 1992), online: Nova Scotia's Electric Flotsam <http:// www.newscotland1398.ca/westray/wraymenu.html>. 
disaster; none of the remaining charges went to trial. ${ }^{7}$ Curragh and two mine managers, Gerald James Phillips and Roger James Parry, were charged with manslaughter and criminal negligence causing death. ${ }^{8}$ Prosecutors stayed the charges in $1998 .^{9}$

The justice system was widely perceived to have failed. The law governing corporate and corporate official criminal liability was a focus of concern. ${ }^{10}$ Legal reform was championed by numerous individuals, organizations, and politicians ${ }^{11}$ — notably by the Westray Families and the United Steelworkers of America. ${ }^{12}$ Through a succession of proposals, recommendations, and Bills, Parliament addressed these issues.

On 7 November 2003, Bill C-45, An Act to amend the Criminal Code (criminal liability of organizations) received Royal Assent. ${ }^{13}$ Bill C-45 put in statutory form, and changed, the common law rules for attributing criminal liability to corporations: it established an express

Brian Bergman, “Westray Charges Stayed,” Maclean's (13 July 1998), online: the Canadian Encyclopedia <http://www.thecanadianencyclopedia.com/articles/macleans/westray-charges-stayed>; see also $R$ v Curragh Inc, [1997] 1 SCR 537, McLachlin and Major JJ (dissenting) at paras 30, 35; Phillips v Nova Scotia (Commission of Inquiry into the Westray Mine Tragedy), [1995] 2 SCR 97 at para 48.

For the prosecutorial saga as reflected in reported cases, see $R v$ Curragh Inc, 1993 CanLII 4461 (NS SC); $R$ v Curragh Inc, 1995 CanLII 4359 (NS CA); $R$ v Curragh Inc, [1995] 1 SCR 900; $R$ v Curragh Inc, 1995 CanLII 4182 (NS CA); $R$ v Curragh Inc, [1997] 1 SCR 537.

$9 \quad$ See Bergman, supra note 7. Curragh Inc filed for bankruptcy in 1993 (Martin O’Malley, "WestrayHere's what happened,” CBC News Online, 9 May 2001, online: Teamsters Canada Rail Conference $<$ http://teamstersrail.ca/TCRC_Westray_Horror.htm>; Smith, supra note 6).

Very briefly, under Canadian common law, corporations could be responsible for both negligence based and mens rea criminal offences. For both types of offences, the act element would be established through acts of corporate agents, such as employees, generally based on conduct within the scope of their duties. The difficulty, then, was to determine how fault could be attributed to the corporation and not simply to the individual perpetrator. Canadian common law relied on an "identification doctrine": a corporate accused would be fixed with the fault of a corporate official who was the "alter ego," "governing executive authority," or "directing mind" for the corporation, acting within the scope of his or her authority - an individual who made policy, not an individual who merely carried out policy (Canadian Dredge \& Dock Co v The Queen, [1985] 1 SCR 662 at 684, 692 [Canadian Dock \& Dredge]; The Rhône $v$ The Peter AB Widener, [1993] 1 SCR 497 at 520-21; Kent Roach, Criminal Law, 5th ed. (Toronto: Irwin Law, 2012) at 231). Fault and act could be variously linked. The directing mind may have personally performed the acts or directed the commission of the acts. In the case of negligence offences, the directing mind would be alleged to have failed to take reasonable steps to prevent the acts or their consequences. A limitation on attributing liability to corporations was that the act must have at least partially benefitted the corporation (Canadian Dock \& Dredge, ibid at 712-14).

11 Justice Richard, while fully cognizant of the constitutional limitations constraining a provincial inquiry, recommended that "[t]he Government of Canada, through the Department of Justice, should institute a study of the accountability of corporate executives and directors for the wrongful or negligent acts of the corporation and should introduce in the Parliament of Canada such amendments to legislation as are necessary to ensure that corporate executives and directors are held properly accountable for workplace safety” (Westray Report, supra note 3, online: Province of Nova Scotia <http://novascotia.ca/ lae/pubs/westray/recommnd.asp>, recommendation 73). On the "convergence of factors" spurring law reform, see Steven Bittle, Still Dying for a Living: Corporate Criminal Liability after the Westray Mine Disaster (Vancouver: UBC Press, 2012) at 23-24, 73, 84-85 [Still Dying for a Living].

12 The United Steelworkers of America had unionized the Westray workers in the spring of 1992, but was not certified until after the explosion (Westray Report, supra note 3, online: Province of Nova Scotia $<$ http://novascotia.ca/lae/pubs/westray/summary.asp>).

13 SC 2003, c 21, in force 31 March 2004 (SI/2004-22). The main provisions are set out in the Appendix to this review. One of the author's concerns was the length of time required for legislative reform; according to him "[t]he process of translating the inquiry's recommendations into Criminal Code legislation was anything but expeditious” (Still Dying for a Living, supra note 11 at 5. See also ibid at 2, 15 ("not exactly a record-breaking pace for such purportedly important legislation")). The reform of criminal law, however, often moves slowly. Consider, for example, the reform of the self-defence rules in 2013, after decades of demand for change (SC 2012, c 9, in force 11 March 2013 (SI/2013-0005); $R$ $v$ McIntosh, [1995] 1 SCR 686 at para 34; Justice Canada, Reforming Criminal Code Defences: Provocation, Self-Defence and Defence of Property: A Consultation Paper (Ottawa: Department of Justice Canada, 1998)). Criticism of delay depends on establishing the relevant baseline time-to-reform. 
duty of care for managers, sentencing factors for corporations, and optional terms of probation for convicted corporations. ${ }^{14}$

Still Dying for a Living ${ }^{15}$ is an account of the formation and implementation of Bill C-45, as it was shaped and limited by legal, economic, and cultural considerations. More generally, it is a critique of the Canadian criminal law approach to corporate and corporate official liability. The method employed is "discourse analysis," informed by the work of Foucault and Althusser. ${ }^{16}$ This approach sounds more forbidding than it is or might have been. The author eschews the impenetrability that is the conceit of much critical theory. Still Dying for a Living is written (for the most part) in a clear and accessible style.

The method employed has both strengths and weaknesses. Discourse analysis is founded on the sensible observation that language - what we say, how we say it, and what we accomplish through saying it - shapes our experience, what we think, and how we act. Language, then, becomes an object of study. Relevant sets of language — “discourses” — are identified and analyzed. The concepts and categorizations, rhetorical ploys and techniques, and express inclusions and implicit exclusions are assessed, providing insight into why we approach our world the way we do. ${ }^{17}$ The author does not permit his method to lead him into a false idealism: while language shapes experience, it does not determine it. ${ }^{18}$ Further, a particular text, such as Bill C-45, should not be understood (deterministically) as being the product of only one species of discourse, hence the consideration of Bill C-45 in light of not only legal, but economic and cultural discourses. ${ }^{19}$ The author sets his analysis within the broader socio-historical contexts in which discourse emerged. ${ }^{20}$ The discourses assessed by the author include statements of politicians and witnesses during Parliamentary processes, responses to the author's interviews with persons involved with the legislative evolution of Bill C-45, as well as some Internet-based materials. ${ }^{21}$ One of the virtues of the book is its documentary account of the development of Bill C-45.

The author approaches his analysis from a particular political position, and he is explicit on this matter. He is interested in "how these discursive formations are constitutive of class struggles over the role of the corporate form in extracting surplus labour and accumulating

Besides broadening responsibility beyond corporations to “organizations,” Bill C-45, ibid, broadened the scope of personnel who may supply the fault for a corporation, by way of sections 22.1 and 22.2 and the definition of "senior officer" in section 2: "senior officer" means a representative [of an organization] who plays an important role in the establishment of an organization's policies or is responsible for managing an important aspect of the organization's activities.” While section 22.2 refers to the mens rea of a single senior officer, negligence (judged on the criminal "marked departure" standard) may be made out through the failings of either a single senior officer or "the senior officers, collectively.” For a discussion of the Bill C-45 innovations, see Todd Archibald, Kenneth Jull \& Kent Roach, "The Changed Face of Corporate Criminal Liability” (2004) 48 Crim LQ 367; Todd Archibald, Kenneth Jull \& Kent Roach, "Critical Developments in Corporate Criminal Liability: Senior Officers, Wilful Blindness, and Agents in Foreign Jurisdictions” (2013) 60 Crim LQ 92 [Archibald, Jull \& Roach].

Still Dying for a Living, supra note 11.

Ibid at 8, 35-36, 56-60.

See generally Mariana Valverde, "Some Remarks on the Rise and Fall of Discourse Analysis” (2000) 33:65 Histoire sociale / Social History 59; Christopher Norris, "Discourse,” in Michael Payne \& Jessica Rae Barbera, eds, A Dictionary of Cultural and Critical Theory, 2d ed (Chichester, West Sussex, UK: John Wiley and Sons, 2010) 190.

Still Dying for a Living, supra note 11 at 7, 56.

Ibid at 59, 64.

Ibid at 9 .

Ibid at 9, 37. 
capital”; ${ }^{22}$ his analysis “[draws] from a fundamental aspect of Marxism — class antagonisms - to consider the extent that class processes are implicated in the (re)production of the capitalist mode of production [and] ... how dominant notions of the capitalist mode of production constitute, and are constituted by, the various discourses that characterize corporate crime and [corporate] criminal liability." 23 This orientation may have a limiting effect on readership. Nonetheless, as Stefan Collini has observed,

there can be no understanding of human history and human self-expression that does not work with categories and concepts that have a political dimension. Where a dominant discourse is unchallenged, these political dimensions can be allowed to remain implicit, effectively invisible, but they are still there.... The drive of theoretical critique is to bring such matters to the surface and to make them the focus of attention. ${ }^{24}$

Discourse analysis is a qualitative discipline, not a quantitative discipline. It issues in interpretations of the discourses assessed. In the author's hands, it does not reveal what was hidden. Instead, as we see below, it draws attention to what was already present, to what was said - often, to what was literally "on the record." It reminds us and provides us with new appreciations of what we already know or should know. In that sense, it may illuminate. But I suggest that discourse analysis proper is very much about what "is" and not about what "ought to be." By itself, analysis does not speak to whether the way the world is shaped is right or wrong. The author's analysis (as might be expected) leads him to the conclusions that the processes leading to Bill C-45 involved the convergence of "relatively autonomous" legal, economic, and cultural discourses, which have reinforced and reproduced the capitalist social formation. ${ }^{25}$ At the same time, Bill C-45 is a tool for challenging corporate power. ${ }^{26}$ One could accept these conclusions, but, for example, be satisfied that, while improvements and corrections may justly be demanded, the set of systems we have in place is nonetheless fundamentally right. The author would consider this reaction to be fundamentally wrong.

The author's analysis is not meant to be simply descriptive. It is to function as "critique," as an indictment of the status quo. Beyond the assessment of language, the author deploys a moral assault on corporate and corporate official criminal liability. Again, the author's politico-moral position is explicit. He is opposed to the "abuses of 'power" and "exploitation" inherent in corporate capitalism. ${ }^{27} \mathrm{He}$ advocates a transformation of "the manner in which surplus values are generated, appropriated, and distributed." 28 The author is clearly angry, outraged by the Westray events, and by the constant toll of workplace death and injury - hence the name of the book. And who could deny the appropriateness of this emotional response? The author's stance is that corporations and their officials are criminals, who are being spared from accountability through legal processes. ${ }^{29}$ The difficulty is that the author does not elaborate his moral arguments. I grant that justifying any version of Marxism is an excessive demand for a book focusing on corporate criminal liability. The author cannot

Ibid at 9.

Ibid at 69.

Stefan Collini, What Are Universities For? (Toronto: Penguin Books, 2012) at 69.

Still Dying for a Living, supra note 11 at 12, 75, 185, 188.

Ibid at 193, 179. In the words of Steve Tombs from the foreword, "it is one material and discursive tool in the struggle for ... accountability" (ibid at xiv).

Ibid at 13 . See also 190.

Ibid at 190 .

Ibid at Xv, 3, 100, 149, 151, 152, 163. 
be faulted for not mounting a defence of Marxism, although there is a danger that the book's ultimate conclusions can only be convincing to one who is already convinced. Regardless of whether or not one adheres to any version of Marxism, however, the issues of what constitutes and what should constitute fault for criminal purposes are clearly fundamental to the book's argument. If corporate officials lack the requisite fault for murder, they are not improperly sheltered from conviction. The book's key weakness is its failure to engage in needed moral analysis. I will review the book's argument, before elaborating my concerns with its critique.

The argument of Still Dying for a Living rests on two indisputable factual premises. First, many types of work are dangerous. Westray was a horrible example of the risks to which workers are exposed, but death or serious injury while working is not an isolated occurrence. ${ }^{30}$ My colleague Gord Winkel has remarked to me that "[w]e have the equivalent of five Westrays a year in Alberta alone.” The statistics bear out that observation. For example, the Association of Workers' Compensation Boards of Canada reported 123 fatalities in Alberta in 2011 and 919 fatalities across Canada. ${ }^{31}$ Alberta Occupational Health and Safety reported 145 fatalities in 2012. ${ }^{32}$ As of 30 June 2013, Alberta has suffered 22 workplace fatalities. ${ }^{33}$ By way of a contrast with traditional crime statistics, across Canada police reported 543 homicides in 2012 and 598 in $2011 .{ }^{34}$ Given that workers are a subset of the total population, workers are at substantially higher risk of death by work than death by (culpable) homicide. ${ }^{35}$

Second, despite the large numbers of deaths and serious injuries that occur in work environments, very few corporate employers or individual managers or other officials are criminally prosecuted for workplace deaths and injuries, and the employers that have been prosecuted have not been among the captains of industry. The author describes the few prosecutions that have followed the enactment of Bill C-45. ${ }^{36}$

Ibid at 3. Of course, workplaces everywhere are dangerous. Recently, 1,127 workers died in the collapse of the Rana Plaza in Savar, Bangladesh (Saeed Ahmed and Leone Lakhani, "Bangladesh building collapse: An end to recovery efforts, a promise of a new start," online: CNN <http://www.cnn.com/ 2013/05/14/world/asia/bangladesh-building-collapse-aftermath>).

31 Association of Workers' Compensation Boards of Canada, "Number of Fatalities, by Jurisdiction, 19932011,” online: Association of Workers' Compensation Boards of Canada <http://www.awcbc.org/ common/assets/nwisptables/all_tables.pdf>, Table 22 (earlier Alberta fatality numbers are: 2003 - 127; 2004 - 124; 2005 - 143; 2006 - 124; 2007 - 154; 2008 - 166; 2009 - 110; 2010 - 136 (ibid)). Alberta Occupational Health and Safety, “2012 Occupational Health and Safety Results,” online: Alberta Human Services <http://humanservices.alberta.ca/documents/2012-OHS-Data.pdf>, Tables 5 and 6. Alberta Occupational Health and Safety, "Workplace Incident Fatalities Accepted by the Workers' Compensation Board in 2013,” online: Alberta Human Services <http://humanservices.alberta.ca/ documents/2013-workplace-fatalities-accepted-wcb.pdf $>$.

34 Samuel Perreault, "Police-reported crime statistics in Canada, 2012" (Canadian Centre for Justice Statistics (25 July 2013), online: Statistics Canada <http://www.statcan.gc.ca/pub/85-002-x/2013001/ article/11854-eng.pdf $>$ at 13 .

35 That being said, we are all at even greater risk of vehicular homicide. In 2010, there were 2,227 deaths caused by reported traffic collisions in Canada. (Transport Canada, "Canadian Motor Vehicle Traffic Collision Statistics: 2010,” online: Transport Canada <http://www.tc.gc.ca/eng/roadsafety/tp1317.htm\#2>). For further contextualization, see the Canadian cause-of-death statistics: Statistics Canada, "Deaths and mortality rate, by selected grouped causes, sex and geography — Canada" (2009), online: Statistics Canada <http://www.statcan.gc.ca/pub/84f0209x/2009000/t001-eng.htm>, Table 1-1. Still Dying for a Living, supra note 11 at 31-34. See Rv Metron Construction Corporation, 2012 ONCJ 506; Cheryl A Edwards, “After Metron: Corporate criminal liability landscape in Canada” (19 July 2012), online: <http://www.cos-mag.com/legal/legal-columns/after-metron-corporate-criminal-liabilitylandscape-in-canada.html>; R c Scrocca, 2010 QCCQ 8218 (although, in this case, the conviction was based on criminal negligence under section 219 of the Criminal Code, section 217.1 was not relied on to attribute fault to the accused); $R$ c Transpavé inc, 2008 QCCQ 1598); “Court Hands Down First 
These premises support two further connected observations. On the one hand, the state's approach to work-related homicide and injury is dissimilar to the approach to non-workrelated homicide and injury. Police-reported homicides are usually cleared through criminal charges. In 2011, consistently with the previous two years, about 76 percent of homicides were "solved" by the police, meaning that at least one person was charged with an offence: "homicide has one of the highest clearance rates among all offences." 37 Evidently, given premise two, work-related homicides are not cleared through criminal charges.

On the other hand, work-related homicide and injury is not simply ignored by the state. Instead of the criminal law, regulatory mechanisms are deployed. This means that the stigma of criminal charges and conviction does not attach to (typically) corporate employers. ${ }^{38}$ Employers deal with regulatory officials, not the police. Employers may be investigated and prosecuted under occupational health and safety legislation. For example, in 2012, Alberta Occupational Health and Safety investigated 23 workplace fatalities; in 2011, it investigated $27 .{ }^{39}$ While the author claims that the penalties faced are less than those for a "street offender who commits comparable acts of theft, fraud, assault, and murder," ${ }^{40}$ setting aside the "comparability" issue, the financial penalties can be quite steep. In 2012, in Alberta, five prosecutions yielded total penalties of between $\$ 70,000$ and $\$ 85,000$ in relation to worker injuries, and three prosecutions yielded total penalties of between $\$ 250,000$ and $\$ 275,000$ in relation to worker fatalities; in another 2012 prosecution in relation to a worker fatality, one corporate accused received a total penalty of $\$ 1.25$ million and a second received a total penalty of $\$ 1.02$ million. ${ }^{41}$ In a 2013 fatality prosecution, the corporate accused received a total penalty of $\$ 1.5$ million. $^{42}$ These are all financial penalties only. There is no indication that individuals were convicted.

Sentence Under new Employer Criminal Negligence Provisions in Criminal Code,” (23 July 2008), online: 215 Labour Law E-Bulletin <http://lancasterhouse.com/pdf/ decisions/up-Criminal.pdf >; $R$ C Pétroles Global Inc, 2012 QCCQ 5749; Archibald, Jull \& Roach (2013), supra note 14 at 99-101, 107113.

Samuel Perreault, “Homicide in Canada, 2011” (Canadian Centre for Justice Statistics: 4 December 2012), online: Statistics Canada <http://www.statcan.gc.ca/pub/85-002-x/2012001/article/11738eng.pdf $>$ at $16,25$.

$38 \quad$ Still Dying for a Living, supra note 11 at 3, 46.

39 Alberta Occupational Health and Safety, “Workplace Incident Fatalities Investigated in 2012,” online: Alberta Human Services <http://humanservices.alberta.ca/documents/2012-workplace-incidentfatalities.pdf $>$ at 2 . Note that these "[f]atality reports ... are published ... after the investigation is complete, and all court proceedings, if any, have been completed" and "[f]igures for workplace incident fatalities investigated by OHS differ from workplace incident fatalities accepted by the Workers' Compensation Board - Alberta (WCB). Common differences in reporting include differences in legal jurisdiction, coverage of applicable Acts and timing" (Alberta Occupational Health and Safety, "Fatality Reports OHS Investigated Workplace Incident Fatalities,” online, Alberta Human Services <http:// humanservices.alberta.ca/working-in-alberta/781.html\#Reports>). Still Dying for a Living, supra note 11 at 100.

41 Alberta Occupational Health and Safety, "Convictions under the Occupational Health and Safety Act," online: Alberta Human Services <http://humanservices.alberta.ca/working-in-alberta/6752.html >. The fatality amounts may seem low. Generally, workers will be covered by the workers' compensation system and survivor benefits will be available (Alberta Workers' Compensation Board, "Work-related fatalities (Benefits for dependents)” (Worker Fact Sheet), online: Alberta Workers' Compensation Board $<$ http://www.wcb.ab.ca/pdfs/workers/WFS_workrelated_fatalities.pdf>).

42 Alberta Occupational Health and Safety, "Convictions under the Occupational Health and Safety Act," supra note 41. For a 2004-2011 Summary of Prosecutions, see Alberta Occupational Health and Safety, “Summary of Prosecutions: Alberta OHS Prosecutions Penalties Summary 2004-2011,” online: Alberta Human Services <http://humanservices.alberta.ca/working-in-alberta/5538.html >. 
The author points out an important - and surprising (even if it is not hidden) difference in the approaches to street crime and non-compliance with worker safety legislation. In the worker safety regulatory area, a "compliance” model is used. Enforcement is approached progressively, with the primary steps relating to education and the securing of voluntary compliance. Prosecution is the last step in the enforcement process. ${ }^{43}$ Alberta's Occupational Health and Safety Compliance Policy and Enforcement Procedures explicitly follow this "compliance" approach. ${ }^{44}$ The author opposes this approach to employer wrongdoing. He favours a more punitive deterrence-based approach — but for corporations and corporate officials, not for street criminals. ${ }^{45}$ The reason appears to be that he considers corporations (unlike street criminals) to be inherently bad or at least suspect. He refers to the immense, virtually inconceivable, social and economic harm caused by corporations. ${ }^{46} \mathrm{He}$ suggests that they have no or little social utility: "even if corporations provide a social benefit (at least theoretically) that street criminals do not." ${ }^{\text {47 }}$ The compliance approach cannot work with corporate villains, because they will falsify and deceive. ${ }^{48}$ The fundamental taint of corporations is that they have a profit motive. ${ }^{49}$ I will only comment that this vision of corporate motivation, action, and impact is bleak and monochromatic.

Workplace death and injury occur. Oversight occurs through regulatory processes, not the criminal law. These are the facts. The contrast, though, is troubling. In the case of non-work related homicide, there is a body, there is an allegation of culpability, there are criminal charges. In the case of work related homicide, there is a body, there is an allegation of culpability, but there are no criminal charges. Why should this contrast exist? Still Dying for a Living brings discourse analysis to bear. The response to workplace death and injury, as manifested in this contrast and in the very language of Bill C-45, betrays economic, cultural, and legal commitments.

The author contends, and he is surely right, that our political system maintains an allegiance to a market economy. ${ }^{50}$ This allegiance was explicit in the Parliamentary discussions relating to corporate criminal liability reform. ${ }^{51}$ Politicians argued that the promotion of corporate economic activity should not be undermined by an excessive or inappropriate use of the criminal law. ${ }^{52}$ The criminal law should not impose obligations on corporations and their officials that would cause corporations to flee Canada for other, less heavy-handed jurisdictions, ${ }^{53}$ or that would deter good people from taking positions of responsibility in corporations. ${ }^{54}$ As the author observes, some of the concerns raised about extending criminal liability during the Bill C-45 proceedings were overblown. Many businesses could not freely and easily uproot themselves from Canada. Their raw materials,

Still Dying for a Living, supra note 11 at 46, 51.

Occupational Health and Safety, L-01a Compliance Policy and Enforcement Procedures, online: Alberta Human Services <http://humanservices.alberta.ca/documents/WHS-OHS-OP-F024.pdf>.

Still Dying for a Living, supra note 11 at 52.

Ibid at 38, 75, 151.

Ibid at $181-82$.

Ibid at $51,152$.

Ibid at 153, 44, 54.

Still Dying for a Living, supra note 11 at 7, 61, 116, 186 (“corporate capitalism," or "neoliberalism”). Ibid at 124,133 , 146. See ibid at 119-24 on the physical absence of corporate Canada from the proceedings.

Ibid at 116 .

Ibid at 125, 129-31.

Ibid at $126-29$. 
work force, infrastructure, and markets may be here. Corporate directors already have plenty of obligations under a variety of federal and provincial statutes as well as owing fiduciary duties to their corporations, yet these obligations have not deterred individuals from serving as directors. While our approach to workplace safety enforcement is doubtless influenced by our economic commitments, it would be fair to observe that some of the Parliamentary commentary was feeble. A methodological point arises. The whole economic story, of course, was not told in Parliamentarians' remarks. Canada's economy involves free markets and state intervention, and governance through internalization, persuasion, regulation, and prosecution. The author would agree that the particular systemic structure of workplace safety enforcement that exists at any given time is the product of multiple business, regulatory, and political interactions. To get the whole story, then, should additional discourse sets have been reviewed? This question engenders further questions: how can it be determined which discourses are the right ones, and when is the selection sufficient? These may be issues for discourse analysis generally. Nevertheless, from one perspective, both my observation and the methodological questions may be beside the point. These Parliamentarians had the authority to decide, and this is what they said.

The author contends - with perhaps less justification than respecting our economic commitments - that we are culturally disposed to overlook the criminal activities of corporations. When we think of "crime," we think of street level violence, individual-onindividual and property offences. ${ }^{55}$ Corporate crime does not fall within the "law and order" agendas of North American governments. ${ }^{56}$ When we think of workplace safety, we do not think of crime, but of "accidents. ${ }^{, 57}$ The author does overstate his case. He claims, for example, that it is "an anathema to label corporations as criminal." ${ }^{58}$ One could well concede that, as a matter of first impression, when we think of crime we do not think of corporations. Yet we are not blind to corporate wrongdoing. Corporate criminal liability has been discussed in all seriousness for decades in law schools. Corporations have been prosecuted for decades - in many cases, for regulatory offences, but more recently for financial offences and corruption offences. The April 2010 British Petroleum (BP) blow-out and oil spill in the Gulf of Mexico which killed 11 workers has been widely reported. BP recently pled guilty to manslaughter and other criminal charges in connection with these events. ${ }^{59}$ The corporate criminal is a trope in popular movies. ${ }^{60}$ Corporate wrongdoing is the subject of investigative documentaries. ${ }^{61} \mathrm{~A}$ more extended examination of cultural discourse relating to corporate liability was warranted; the discourse may well be shot through with more currents than the author acknowledged. We thus encounter the same sort of "selection of discourses" problem referred to above.

Ibid at 150-51, 181.

Ibid at 157.

Ibid at 93, 105, 149.

Ibid at 149 .

Clifford Krauss, “Judge Accepts BP’s \$4 Billion Criminal Settlement Over Gulf Oil Spill” (29 January 2013), online: New York Times <http://www.nytimes.com/2013/01/30/business/judge-approves-bpcriminal-settlement.html?_r=0>.

60 Consider, for example, the Resident Evil series (Umbrella Corporation); The Sixth Day (Replacement Technologies); and the Aliens series (Weyland-Yutani Corporation).

61 For example, The World According to Monsanto, 2008 DVD; Food, Inc., 2008 DVD; Gasland, 2010 DVD. 
The author contends that legal discourse blocked attempts to expand corporate and officials' liability. It narrowed horizons and limited reform options. ${ }^{62}$ His assessment is correct. The particular focus of this concern in the Westray context was the proposal that liability be assessed on a "corporate culture" basis. Under the identification doctrine, a corporation could be criminally liable if a "directing mind” had the requisite knowledge and intent or was negligent. Finding a particular individual with both the requisite authority and fault may be difficult. Yet the "corporation" — not identified with any particular individual - might be found to have encouraged the act through its "culture." The culture of a corporation may be criminogenic — tending to produce, or at the very least encourage, law breaking. ${ }^{63}$ Assigning liability on a corporate culture basis would recognize the unique and complex structural features of corporate activity. ${ }^{64}$ Bill C-284, a New Democrat-sponsored forerunner of Bill C-45, proposed the imposition of both corporate and corporate officer liability through "corporate culture":

467.3 (2) Where it is shown that an act or omission has been committed on behalf of a corporation, directly or indirectly by the act or pursuant to the order of one or more of its officers, employees or independent contractors, and

(c) the management of the corporation had allowed the development of a culture or common attitude among its officers and employees that encouraged them to believe that the act or omission would be tolerated, condoned or ignored by the corporation ...

the corporation is guilty of every offence of which an individual could be found guilty for committing that act or omission. ...

467.4 (1) Every one who is a director or officer of a corporation that is guilty of an offence under section 467.3 who ...

(b) knew or ought to have known, as a result of circumstances described in paragraph 467.3(2)(b), (c) or (d) that the act or omission that constituted the offence was being committed, or would or would be likely to take place, and failed to take all reasonable steps to prevent its commission ...

is guilty of an offence and liable on conviction as if committed personally and liable to the same penalty as if the director or officer had committed the act or omission personally. ${ }^{65}$

$62 \quad$ Still Dying for a Living, supra note 11 at 45, 107, 113.

Ibid at 104.

Ibid at $45,89$.

Bill C-284, An Act to amend the Criminal Code (offences by corporations, directors and officers), 1st Sess, 37th Parl, online: Parliament of Canada <http://www.parl.gc.ca/HousePublications/ Publication.aspx? Language=E\&Mode=1\&DocId=2331142>; Still Dying for a Living, supra note 11 at 103. 
The corporate culture approach was rejected for two main reasons, both founded on the Canadian Charter of Rights and Freedoms. ${ }^{66}$ First, the "culture or common attitude" test could not be described with sufficient specificity; it would be found void for vagueness and so would not be a constitutionally sustainable standard for criminal liability. ${ }^{67}$ Second, the attribution of liability requires proof of responsibility or fault. Fundamental justice demands that if an individual may be imprisoned for an offence, he or she must at least be personally found to have been negligent (in the criminal sense). ${ }^{68}$ Hence, to satisfy constitutional strictures, personal fault must be brought home to a corporate official facing criminal punishment. Fault residing elsewhere, such as in the culture of a corporation, is insufficient. Furthermore, fault that is neither intent nor negligence but "cultural encouragement or condonation" does not meet the minimum fault standard. So the legal discourse did indeed "remain focused on individual fault.",69

An important corollory of the author's argument is that the language of the law itself limits corporate and corporate official liability. Law's discourse pushes corporate criminality from the gaze of criminal process. ${ }^{70}$ This means that fixing the Westray problem is not simply a matter of resources and priorizing corporate misconduct; the solution does not lie in better enforcement (or with less coercive mechanisms). Put another way, if the author is right, the problems cannot be solved within the system, but only by changing the system.

For our purposes, the important questions is whether the law has it wrong, and if so, why? The author's critical attitude toward law is complex. I will try to untangle a few strands.

The author attempts to shake the authority of law. He is opposed to the vision of law as “capital ' $\mathrm{T}$ ' Truth," as an infallible benchmark or touchstone. ${ }^{71}$ Law claims the "right to speak truth" because it claims "to embody key cultural values of fairness, liberty, and equality and its ability to speak in the name of universal human rights." "72 Law's roots, however, lie in "gendered, racialized, and capitalist experiences," and it recreates a "gendering practice,” a "racialized space,” and a "capitalist ideology."73 Law, though, is not wholly an oppressor's tool. It is complex and contradictory. It is not unidirectional; it does

Canadian Charter of Rights and Freedoms, Part I of the Constitution Act, 1982, being Schedule B to the Canada Act 1982 (UK), 1982, c 11 [Charter].

Still Dying for a Living, supra note 11 at $97,107-109,110$. "A law is unconstitutionally vague if it "does not provide an adequate basis for legal debate" and "analysis"; "does not sufficiently delineate any area of risk"; or "is not intelligible." The law must offer a "grasp to the judiciary" ( $R v$ Nova Scotia Pharmaceutical Society, [1992] 2 SCR 606 at 639-40). Certainty is not required" (Canadian Foundation for Children, Youth and the Law v Canada (Attorney General), [2004] 2004 SCC 4, 1 SCR 76 at para 15).

Re BC Motor Vehicle Act, [1985] 2 SCR 486 at 515; Still Dying for a Living, supra note 11 at 96. On the constitutional requirements for the criminal negligence standard, see $R v$ Creighton, [1993] 3 SCR 3 at 59.

$69 \quad$ Still Dying for a Living, supra note 11 at 30, 92-94, 98. One might also observe, although this point does not seem to have been raised in connection with Bill C-284, that for centuries the criminal law has resisted conviction solely on the basis of the character of the accused, an orientation confirmed by the general rule forbidding the Crown to introduce evidence of bad character of the accused (see e.g. $R v$ $B(F F)$, [1993] 1 SCR 697 at 730). "Corporate culture" is a form of corporate character (not even individual character). Again, culture-based fault goes against the grain of the law. Are there good reasons to jettison this rule of evidence?

Still Dying for a Living, supra note 11 at 73, 101-102, 149.

Ibid at $85,87,88,100$.

Ibid at 86.

Ibid at 86, 100, 156. 
not completely silence counter-hegemonic discourses. ${ }^{74}$ Bill C-45 itself is a means for holding corporations to account. ${ }^{75}$

A difficulty is that the author's vision of infallible law may not be shared by anyone else. No one familiar with the law would claim that the law - whether common law, statute, regulation, or constitutional provisions and interpretations - is "capital ' $\mathrm{T}$ ' Truth." Admittedly, there are many areas of law that are settled for practical purposes. Part of the job of the law is to provide stability and predictability to interpersonal transactions. Yet at the same time, the law changes constantly, sometimes only modestly and incrementally, sometimes quite radically, as when a new legislative approach to some area is adopted or when the scope of a constitutional provision is judicially expanded. Change is not blocked by an article of faith that the way things are now is perfect; change is motivated by the recognition that current rules are imperfect and by the hope that new provisions will be improvements and approach the ideal more closely. Further, no one would dispute that laws have been bad, that laws have discriminated, that laws have been means for oppression. Yet injustices have been corrected without revolution. Injustices have been corrected in the courts, through democratic processes, and through exercising constitutionally-protected rights, all through the power of rational argument. It is precisely because the legal system does rest on principles of fairness, liberty, and equality that these changes were possible within the system. And these are "principles," not detailed instructions in a manual. No one would dispute that our understanding of these principles can change. We are learning, slowly, to understand these principles more fully. Justice is the work of generations.

A further difficulty in responding to the author is that his position respecting "fairness, liberty, and equality” is not clear. He could be rejecting the status of such notions as legal principles, that is, as principles animating the rule of law. They could be but words used as weapons in class conflict. That approach would mean that the author could not be seeking any moral high ground against his capitalist foes. There is no "high ground," there is only conflict, and the only issue is whether you are with him or not. If the author accepts that such notions do play a role as legal principles animating the rule of law, and if the rule of law is "a cultural achievement of universal significance,"76 then it is possible that even our courts, and their acolytes could have gotten some aspects of these principles right.

The problem, regardless of other alleged defects or virtues of the law, is whether a requirement that an individual be at fault (whether fault is subjective or objective) is a condition for imposing criminal punishment. This is not a question only for a "bourgeois" legal system but any legal system. ${ }^{77}$ Can an organizational disposition be a proxy for individual wrongdoing? Of course, we can conceive of imposing punishment on someone who is not at fault (there is such a thing as an "absolute liability offence"), but is it just to impose the stigma of conviction and imprisonment without fault? The Supreme Court of Canada thought not. Consequently, did the learned justices get it wrong? The author does not

Ibid at 53, 86, 87. A difficulty, which I shall not pursue, is whether the talk about the "contradictory" nature of the State and law entails that the Marxist approach is tautological. The position is consistent with any state of affairs. The position is unfalsifiable. Ibid at 88, 193.

EP Thompson, Whigs and Hunters: The Origin of the Black Act (Markham, Ontario: Penguin Books, 1975) at 265.

See e.g. Harold J Berman, “Principles of Soviet Criminal Law” (1947) 56:5 Yale LJ 803 at 818. 
engage in argument on this level. He does not give us reasons for thinking the court got it wrong. He seems to avoid the problem of what is fundamentally just: "These concerns outweighed any desires to push the legal envelope - better to take the conservative [route] and stick with the familiar than upset the legal status quo in the face of unique problems that lie outside of traditional criminal law concerns with (street) crime."78 The issue is not one of simply choosing this or that legislative approach, as if there were no constitutional constraints or constraints of fundamental justice. The problem is whether a particular legislative approach should or should not be adopted. It is not unfair to put the burden of proving error on the author, since he is advancing the claim that the courts and the law are wrong.

What the author does point out is that an effect of the fault rules is that corporate officials can avoid punishment, because they can avoid the knowledge and decisions that could attract a finding of fault and because of the difficulty of securing evidence. The fault rules function as a shield for corporate criminals. ${ }^{79}$ One response is that this contention begs the question of whether or not corporate officials are at fault. If they are not, they are not being "shielded." Only if they are at fault are they being "shielded" — but then we return to the problem of how they can be at fault if they lack personal objective or subjective fault. The fact that we would like to blame someone does not make that someone blameworthy. Moreover, the author provides no moral reasons for attributing liability to corporate officials on a lower level of fault than might apply to other individuals.

Another response is to acknowledge the partial truth in the previous quotation. Fault is indeed a "traditional criminal law concern." As such, its evolution had little or nothing to do with the liability of corporate officials. Engineering a shield through the traditional fault rules lies beyond the capacity of even corporate interests. There was no insidious functionality at work in the evolution of the fault rules.

Yet another response turns again on the previous quotation and on the author's contention that the corporate official liability problem is “unique.” It is not. I grant that at least the early criminal law was not faced by huge transnational enterprises, with their hierarchies, levels of knowledge and information, and levels of authority. One of the traditional problems of the traditional criminal law, though, has been offences committed by groups of individuals. Offences might be committed by a small number of individuals in an ad hoc alliance, by an organized but hierarchically "flat" street gang, or by a large and hierarchically-structured criminal organization. More recently, the law has had to contend with international terrorist organizations, involving networks of more-or-less autonomous cells with dispersed and decentralized command and control. In all of these circumstances, acts may be physically committed by one or only some group members. Tracking fault for non-actors can be practically difficult, but the development of rules to cover these sorts of circumstances has been a concern of the traditional law. 
The law has doctrines that permit the attribution of fault and criminal liability to individuals other than principal offenders. We have the doctrines of secondary liability ${ }^{80}$ and conspiracy.$^{81}$ We have the doctrine of willful blindness. ${ }^{82}$ Todd Archibald, Kenneth Jull, and Kent Roach, I note, emphasize the importance of the willful blindness doctrine in corporate prosecutions. ${ }^{83}$ The state, moreover, has plenty of investigative means at its disposal, including wide-ranging warrant and "wiretap" authority. Undercover agents may be inserted into organizations, and organization members may be turned. Law enforcement in the United States was able to bring La Cosa Nostra to its knees. ${ }^{84}$ Corporate Canada, if it becomes involved in criminal matters, should prove less of an adversary.

As a final fault point, the author laments our "inability to equate workplace injury and death with violence and murder." 85 Our "inability" turns on fault. If the fault for murder is absent, then we cannot properly attribute responsibility for murder. We should avoid calling things by the wrong name. ${ }^{86}$

Assume that fault, conceived along traditional lines, is required for the conviction of corporate officials as much as for other accuseds. Another issue (not pursued by the author) is whether justice demands that corporations be convicted only on proof of fault. An argument might be made that (1) corporations are not directly protected under section 7 of the Charter; ${ }^{87}$ (2) corporations, then, would not have a section 7-guaranteed "proof of fault" right; and (3) a rule permitting conviction of corporations (not individuals) without proof of fault would not violate section 7. A corporation, then, could face some form of no-fault vicarious liability for acts of employees, if those acts were suitably linked to the corporation (for example, the act was performed within the scope of employee duties, one consequence of the act was benefit for the corporation, and the perpetrator personally committed an offence). The difficulties of both the identification theory and the "corporate culture" model could be side-stepped. ${ }^{88}$

Criminal Code, RSC, 1985, c C-46, ss 21-23.1, 464.

Ibid, s 465.

Justice Charron provided the following description of "willful blindness" in $R v$ Briscoe, 2010 SCC 13, [2010] 1 SCR 411 at para 21: "Wilful blindness does not define the mens rea required for particular offences. Rather, it can substitute for actual knowledge whenever knowledge is a component of the mens rea. The doctrine of wilful blindness imputes knowledge to an accused whose suspicion is aroused to the point where he or she sees the need for further inquiries, but deliberately chooses not to make those inquiries.” See Sansregret v The Queen, [1985] 1 SCR 570; R v Jorgensen, [1995] 4 SCR 55. As Justice Sopinka succinctly put it in Jorgensen (at para 103 [emphasis omitted]), "[a] finding of wilful blindness involves an affirmative answer to the question: Did the accused shut his eyes because he knew or strongly suspected that looking would fix him with knowledge?”

Archibald, Jull \& Roach, supra note 14 at 118.

See e.g. James B Jacobs, Busting the Mob: United States v Cosa Nostra (New York: New York University Press, 1994).

Still Dying for a Living, supra note 10 at 163.

$R v$ Vaillancourt, [1987] 2 SCR 636 at 653-54; $R v$ Martineau, [1990] 2 SCR 633 at 646-47. "If names be not correct, language is not in accordance with the truth of things. If language be not in accordance with the truth of things, affairs cannot be carried on to success. When affairs cannot be carried on to success, proprieties and music do not flourish. When proprieties and music do not flourish, punishments will not be properly awarded. When punishments are not properly awarded, the people do not know how to move hand or foot" (Confucius, The Analects, Part 13, online: The Internet Classics Archive $<$ http://classics.mit.edu/Confucius/analects.3.3.html>).

$R v$ Wholesale Travel Group Inc, [1991] 3 SCR 154 at 181; Archibald, Jull \& Roach, supra note 14 at 102.

With respect to an aspect of "corporate culture" left dangling: an argument might be made that, even if corporations are not directly protected under section 7 of the Charter, corporations may still advance a "void for vagueness" argument. Arguably, the requirement that offences provide a sufficiently certain standard to guide action and constrain law enforcement direction is a principle not only protected under 
If criminal vicarious liability for corporations were possible, what would be the point of legislating it? Conviction would not confirm intention or malice; it would not confirm negligence. It would confirm no fault at all. Conviction would support a penalty, but that penalty could only be financial. From a penalty perspective, the result is similar to the result following conviction under provincial occupational health and safety legislation. From a "moral" perspective, the criminal conviction would signify less than a provincial conviction. Occupational health and safety offences are typically strict liability offences. These offences are premised (in effect) on a finding of negligence. Employers can avoid liability if they can establish that they acted with due diligence or that they took reasonable steps to avoid the harm in the circumstances.

These musings tie back to Still Dying for a Living. One of the author's dissatisfactions is that the bulk of workplace safety enforcement is carried by provincial officials under provincial occupational health and safety legislation rather than under the Criminal Code. ${ }^{89}$ If the price of expanded criminalization is lowered corporate fault, what would be gained? The author frequently contends that "crime" is socially constructed; the distinctions between criminal offences and regulatory offences are arbitrary. ${ }^{90}$ If the criminal label is arbitrary, it should not matter whether the conduct is called criminal or not, so long as it is dealt with by the state and penalties are assessed. If the application of the "criminal" label is not merely arbitrary and the wrongdoing of the corporation should be properly labeled, then the author may be presupposing a form of desert theory. The stigma and punishment following criminal conviction are morally appropriate to the nature of the corporation's wrongdoing. No such express argument is made.

Still Dying for a Living is provocative and challenging. It raises many issues that I have not addressed. In my view, its outrage at the failure to bring the Westray accuseds to trial and at the light treatment other employers have doubtless received when workers have died is entirely justified. In my view as well, the author is right that our arrangements governing workplace safety are the product of the intersection of economic, cultural, and legal factors, all mediated by politics. I am not convinced, though, that the foundations of the author's critique are justified or fully thought through. This may be a limitation of a genre.

\author{
Wayne Renke \\ Professor \\ Faculty of Law \\ University of Alberta
}

section 7, but a principle of the rule of law referred to in the preamble to the Charter ("Whereas Canada is founded upon principles that recognize ... the rule of law"); it may also be an "unwritten" constitutional principle (see Reference re Remuneration of Judges of the Provincial Court (P.E.I.), [1997] 3 SCR 3 at para 83). The suggestion that a corporation could be convicted by a vague law seems contrary to our rule of law tradition: $R v$ Levkovic, 2013 SCC 25, 359 DLR (4th) 197 at paras 1-3, 33-35, 37. 


\section{APPENDIX: \\ EXTRACTS FROM BILL C-45, AN ACT TO AMEND THE CRIMINAL CODE ${ }^{91}$}

\section{CRIMINAL CODE}

1. (2) Section 2 of the Act is amended by adding the following in alphabetical order:

“organization” means

(a) a public body, body corporate, society, company, firm, partnership, trade union or municipality, or

(b) an association of persons that

(i) is created for a common purpose,

(ii) has an operational structure, and

(iii) holds itself out to the public as an association of persons;

"representative”, in respect of an organization, means a director, partner, employee, member, agent or contractor of the organization;

"senior officer" means a representative who plays an important role in the establishment of an organization's policies or is responsible for managing an important aspect of the organization's activities and, in the case of a body corporate, includes a director, its chief executive officer and its chief financial officer;

\section{The Act is amended by adding the following after section 22:}

22.1 In respect of an offence that requires the prosecution to prove negligence, an organization is a party to the offence if

(a) acting within the scope of their authority

(i) one of its representatives is a party to the offence, or

(ii) two or more of its representatives engage in conduct, whether by act or omission, such that, if it had been the conduct of only one representative, that representative would have been a party to the offence; and

(b) the senior officer who is responsible for the aspect of the organization's activities that is relevant to the offence departs - or the senior officers, collectively, depart - markedly from the standard of care that, in the circumstances, could reasonably be expected to prevent a representative of the organization from being a party to the offence. 
22.2 In respect of an offence that requires the prosecution to prove fault - other than negligence - an organization is a party to the offence if, with the intent at least in part to benefit the organization, one of its senior officers

(a) acting within the scope of their authority, is a party to the offence;

(b) having the mental state required to be a party to the offence and acting within the scope of their authority, directs the work of other representatives of the organization so that they do the act or make the omission specified in the offence; or

(c) knowing that a representative of the organization is or is about to be a party to the offence, does not take all reasonable measures to stop them from being a party to the offence.

\section{The Act is amended by adding the following after section 217:}

217.1 Every one who undertakes, or has the authority, to direct how another person does work or performs a task is under a legal duty to take reasonable steps to prevent bodily harm to that person, or any other person, arising from that work or task.

\section{The Act is amended by adding the following after section 718.2:}

718.21 A court that imposes a sentence on an organization shall also take into consideration the following factors:

(a) any advantage realized by the organization as a result of the offence;

(b) the degree of planning involved in carrying out the offence and the duration and complexity of the offence;

(c) whether the organization has attempted to conceal its assets, or convert them, in order to show that it is not able to pay a fine or make restitution;

(d) the impact that the sentence would have on the economic viability of the organization and the continued employment of its employees;

(e) the cost to public authorities of the investigation and prosecution of the offence;

(f) any regulatory penalty imposed on the organization or one of its representatives in respect of the conduct that formed the basis of the offence;

(g) whether the organization was - or any of its representatives who were involved in the commission of the offence were - convicted of a similar offence or sanctioned by a regulatory body for similar conduct; 
(h) any penalty imposed by the organization on a representative for their role in the commission of the offence;

(i) any restitution that the organization is ordered to make or any amount that the organization has paid to a victim of the offence; and

(j) any measures that the organization has taken to reduce the likelihood of it committing a subsequent offence.

\section{8. (2) Section 732.1 of the Act is amended by adding the following after subsection (3):}

(3.1) The court may prescribe, as additional conditions of a probation order made in respect of an organization, that the offender do one or more of the following:

(a) make restitution to a person for any loss or damage that they suffered as a result of the offence;

(b) establish policies, standards and procedures to reduce the likelihood of the organization committing a subsequent offence;

(c) communicate those policies, standards and procedures to its representatives;

(d) report to the court on the implementation of those policies, standards and procedures;

(e) identify the senior officer who is responsible for compliance with those policies, standards and procedures;

(f) provide, in the manner specified by the court, the following information to the public, namely,

(i) the offence of which the organization was convicted,

(ii) the sentence imposed by the court, and

(iii) any measures that the organization is taking — including any policies, standards and procedures established under paragraph (b) — to reduce the likelihood of it committing a subsequent offence; and

(g) comply with any other reasonable conditions that the court considers desirable to prevent the organization from committing subsequent offences or to remedy the harm caused by the offence.

(3.2) Before making an order under paragraph (3.1)(b), a court shall consider whether it would be more appropriate for another regulatory body to supervise the development or implementation of the policies, standards and procedures referred to in that paragraph. 
20. (1) The portion of subsection 735(1) of the Act before paragraph (a) is replaced by the following:

735. (1) An organization that is convicted of an offence is liable, in lieu of any imprisonment that is prescribed as punishment for that offence, to be fined in an amount, except where otherwise provided by law,

(2) Paragraph 735(1)(b) of the Act is replaced by the following:

(b) not exceeding one hundred thousand dollars, where the offence is a summary conviction offence. 